Bull. Mater. Sci., Vol. 13, No. 3, June 1990, pp. 179-189. (C) Printed in India.

\title{
Combustion synthesis and properties of fine particle fluorescent aluminous oxides $\dagger$
}

\author{
J J KINGSLEY, N MANICKAM ${ }^{\dagger}+$ and K C PATIL* \\ Department of Inorganic and Physical Chemistry, and ††Department of Physics, \\ Indian Institute of Science, Bangalore 560012 , India
}

MS received 17 July 1989; revised 17 October 1989

\begin{abstract}
Fine particle fluorescent aluminous oxide materials like $\mathrm{Cr}^{3+}$-doped $\alpha-\mathrm{Al}_{2} \mathrm{O}_{3}$ (ruby), $\mathrm{MgAl}_{2} \mathrm{O}_{4}, \mathrm{LaAlO}_{3}, \mathrm{Y}_{3} \mathrm{Al}_{5} \mathrm{O}_{12}$ and $\mathrm{Ce}^{3+}$-doped $\mathrm{Y}_{3} \mathrm{Al}_{5} \mathrm{O}_{12}, \quad \mathrm{LaMgAl}{ }_{11} \mathrm{O}_{19}$, $\mathrm{CaAl}_{12} \mathrm{O}_{19}$ and $\mathrm{CeMgAl}_{11} \mathrm{O}_{19}$ have been prepared by the combustion of the corresponding metal nitrate-aluminium nitrate-urea/carbohydrazide mixtures at $500^{\circ} \mathrm{C}$ in less than $5 \mathrm{~min}$. Formation of these $\mathrm{Cr}^{3+}$ - and $\mathrm{Ce}^{3+}$-doped aluminous oxides has been confirmed by their characteristic XRD, colour, UV-visible and fluorescence spectra as well as decay time measurements. Ruby $\left(\mathrm{Cr}^{3+} / \alpha-\mathrm{Al}_{2} \mathrm{O}_{3}\right)$ powder showed characteristic excitation bands at 406 and $548 \mathrm{~nm}$ and emission band at $695 \mathrm{~nm}$ with the decay time of $3.6 \mathrm{~ms}$.
\end{abstract}

Keywords. Ruby powder; combustion synthesis; urea; carbohydrazide; aluminium nitrate; metal nitrates; lasers; TV phosphors; fluorescent aluminous oxides.

\section{Introduction}

Transition metal or rare earth element-doped aluminous oxides are of technological importance due to their applications as lasers $\left(\mathrm{Cr}^{3+} / \alpha-\mathrm{Al}_{2} \mathrm{O}_{3}\right.$, ruby; $\mathrm{Cr}^{3+} / \mathrm{LaAlO}_{3}$, $\mathrm{Nd}^{3+} / \mathrm{Y}_{3} \mathrm{Al}_{5} \mathrm{O}_{12}, \mathrm{Nd}$ :YAG) (Geusic et al 1966; Cokayne 1972; Hannay 1973), TV phosphors and in fluorescent lamps $\left(\mathrm{Ce}^{3+} / \mathrm{CaAl}_{12} \mathrm{O}_{19}\right)$ (Scholten and Eijnthoven 1985; Wolfe 1978). These oxides need to be fine particles for use in TV screens and lamps. Recently it was proposed that sub-micron size particles can exhibit optical bistability in the scattering and absorption of light (Leunng 1986). Hence, fine particles of $\mathrm{Cr}^{3+}$ doped $\alpha-\mathrm{Al}_{2} \mathrm{O}_{3}$ (ruby) may be used for ultrafine lasers and ultrafine optical devices (Hirai et al 1987).

The conventional method of preparing these transition metal or rare earth-doped aluminous oxide powders is the ceramic method involving the solid state reactions of metal nitrate-urea mixtures (Kingsley et al 1988, 1990; Kingsley and Patil 1988). $\mathrm{Cr}_{2} \mathrm{O}_{3}-\mathrm{Al}_{2} \mathrm{O}_{3}\left(1350^{\circ} \mathrm{C}, 96 \mathrm{~h}\right)$ (De Biasi and Rodrigues 1981), $\mathrm{Cr}_{2} \mathrm{O}_{3}-\mathrm{MgAl}_{2} \mathrm{O}_{4}$ $\left(1250^{\circ} \mathrm{C}, 10 \mathrm{~h}\right.$ ) (Gillen and Salomon 1970). Fine particles of these doped oxides have been prepared by the sol-gel process e.g. ruby (Hirai et al 1987), which is also quite involved and expensive.

Recently, a novel combustion process has been developed for the instant synthesis of fine particle $\alpha$-alumina and related oxides employing aqueous solutions of metal nitrate-urea mixtures (Kingsley et al 1988, 1990; Kingsley and Patil 1988). It was therefore, considered feasible to employ. the combustion process to incorporate desired concentrations of impurity ions like $\mathrm{Cr}^{3+}$ or $\mathrm{Ce}^{3+}$ and prepare fine particle fluorescent aluminous oxide materials such as $\mathrm{Cr}^{3+}$-doped $\alpha-\mathrm{Al}_{2} \mathrm{O}_{3}$ (ruby), $\quad \mathrm{MgAl}_{2} \mathrm{O}_{4}, \quad \mathrm{LaAlO}_{3}, \mathrm{Y}_{3} \mathrm{Al}_{5} \mathrm{O}_{12}, \mathrm{Ce}^{3+}$-doped $\mathrm{Y}_{3} \mathrm{Al}_{5} \mathrm{O}_{12}, \mathrm{CaAl}_{12} \mathrm{O}_{19}$, $\mathrm{LaMgAl}_{11} \mathrm{O}_{19}$ and $\mathrm{CeMgAl}_{11} \mathrm{O}_{19}$. The results of these investigations are presented in this paper.

TPresented at the "Materials Research Society (India) Foundation Meeting", Defence Metallurgical Research Laboratory, Hyderabad, India, February 10-11 (1989).

*For correspondence. 


\section{Experimental}

$\mathrm{Cr}^{3+}$-and $\mathrm{Ce}^{3+}$-doped aluminous oxides such as $\mathrm{Cr}^{3+} / \mathrm{Al}_{2} \mathrm{O}_{3}, \mathrm{MgAl}_{2} \mathrm{O}_{4}, \mathrm{LaAlO}_{3}$ and YAG; $\mathrm{Ce}^{3+} / \mathrm{YAG}, \mathrm{CaAl}_{12} \mathrm{O}_{19}$ and $\mathrm{LaMgAl}_{11} \mathrm{O}_{19}$ were prepared by the combustion of mixtures containing the corresponding metal nitrate-aluminium nitrate-urea/carbohydrazide mixtures with the desired concentrations of the dopant ions.

Actual compositions used for the combustion synthesis of $\mathrm{Cr}^{3+}$ and $\mathrm{Ce}^{3+}$ doped aluminous oxides are given in table 1 . The stoichiometric compositions of the mixtures were calculated using the $\mathrm{O} / \mathrm{F}$ ratio used for the preparation of the host lattices described earlier (Kingsley and Patil 1988; Kingsley et al 1988, 1990) except for the addition of dopant ions in the form of respective metal nitrates. The concentrations of the dopant ions are given in terms of weight percentages e.g. $0.05 \% \mathrm{Cr}^{3+} / \alpha-\mathrm{Al}_{2} \mathrm{O}_{3}$ implies $0.05 \mathrm{~g}$ of $\mathrm{Cr}_{2} \mathrm{O}_{3}$ in $100 \mathrm{~g} \alpha-\mathrm{Al}_{2} \mathrm{O}_{3}$.

The preparations of $0.5 \% \mathrm{Cr}^{3+} / \mathrm{Al}_{2} \mathrm{O}_{3}$ (ruby powder) and $0.05 \% \mathrm{Ce}^{3+} /$ YAG have been described below as representative for all fluorescent aluminous oxides.

\subsection{Combustion synthesis of fine particle ruby powder $\left(0.5 \% \mathrm{Cr}^{3+} / \alpha-\mathrm{Al}_{2} \mathrm{O}_{3}\right)$}

$\mathrm{Al}\left(\mathrm{NO}_{3}\right)_{3} \cdot 9 \mathrm{H}_{2} \mathrm{O}(20 \mathrm{~g})$ and urea $(8 \mathrm{~g})$ are dissolved in a minimum quantity of water along with $\mathrm{Cr}\left(\mathrm{NO}_{3}\right)_{3} \cdot 6 \mathrm{H}_{2} \mathrm{O}\left(0.07 \mathrm{gg}\right.$ ) (corresponding to $0.5 \% \mathrm{Cr}^{3+} / \alpha-\mathrm{Al}_{2} \mathrm{O}_{3}$, i.e. $0.5 \mathrm{~g} \mathrm{Cr}_{2} \mathrm{O}_{3}$ for $\left.100 \mathrm{~g} \alpha-\mathrm{Al}_{2} \mathrm{O}_{3}\right)$ in a cylindrical pyrex dish $(100 \mathrm{~mm}$ dia $\times 50 \mathrm{~mm}$ height) of approximately $300 \mathrm{ml}$ capacity. The dish containing the solution is

Table 1. Compositions of the combustion mixtures.

\begin{tabular}{|c|c|c|c|c|}
\hline \multicolumn{4}{|c|}{ Compositions of the combustion mixtures* } & \multirow{2}{*}{$\begin{array}{l}\text { Fluorescent oxide } \\
\text { (colour) } \\
\begin{array}{l}0.05 \% \mathrm{Cr}^{3+} / \mathrm{Al}_{2} \mathrm{O}_{3} \\
\text { (pink) }\end{array}\end{array}$} \\
\hline A & $\begin{array}{c}+\mathrm{Cr}\left(\mathrm{NO}_{3}\right)_{3} \\
(0.007 \mathrm{~g})\end{array}$ & & $\begin{array}{c}+ \text { urea } \\
(8.0 \mathrm{~g})\end{array}$ & \\
\hline A & $\begin{aligned}+ & \mathrm{Mg}\left(\mathrm{NO}_{3}\right)_{2} \cdot 6 \mathrm{H}_{2} \mathrm{O} \\
& (6.83 \mathrm{~g})\end{aligned}$ & $\begin{aligned}+ & \mathrm{Cr}\left(\mathrm{NO}_{3}\right)_{3} \cdot 6 \mathrm{H}_{2} \mathrm{O} \\
& (0 \cdot 007 \mathrm{~g})\end{aligned}$ & $\begin{array}{l}+ \text { urea } \\
(10.7 \mathrm{~g})\end{array}$ & $\begin{array}{l}0.05 \% \mathrm{Cr}^{3+} / \mathrm{MgAl}_{2} \mathrm{O}_{4} \\
\text { (pink) }\end{array}$ \\
\hline $\mathbf{A}$ & $\begin{aligned}+ & \mathrm{La}\left(\mathrm{NO}_{3}\right)_{3} \cdot 6 \mathrm{H}_{2} \mathrm{O} \\
& (23.08 \mathrm{~g})\end{aligned}$ & $\begin{aligned}+ & \mathrm{Cr}\left(\mathrm{NO}_{3}\right)_{3} \cdot 6 \mathrm{H}_{2} \mathrm{O} \\
& (0.007 \mathrm{~g})\end{aligned}$ & $\begin{array}{l}+ \text { urea } \\
\quad(16.0 \mathrm{~g})\end{array}$ & $\begin{array}{l}0.05 \% \mathrm{Cr}^{3+} / \mathrm{LaAlO}_{3} \\
\text { (pink) }\end{array}$ \\
\hline $\mathbf{A}$ & 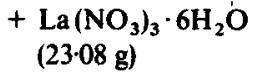 & $\begin{aligned}+ & \mathrm{Cr}\left(\mathrm{NO}_{3}\right)_{3} \cdot 6 \mathrm{H}_{2} \mathrm{O} \\
(0.007 \mathrm{~g}) & \end{aligned}$ & $\begin{array}{l}+ \text { carbohydrazide } \\
(14.4 \mathrm{~g})\end{array}$ & $\begin{array}{l}0.05 \% \mathrm{Cr}^{3+} / \mathrm{LaAlO}_{3} \\
\text { (pink) }\end{array}$ \\
\hline $\mathbf{A}$ & $\begin{array}{l}+\mathrm{Y}\left(\mathrm{NO}_{3}\right)_{3} \cdot 6 \mathrm{H}_{2} \mathrm{O} \\
(12 \cdot 252 \mathrm{~g})\end{array}$ & $\begin{array}{l}+\underset{(0.0084 \mathrm{~g})}{\mathrm{Ce}\left(\mathrm{NO}_{3}\right)_{3} \cdot 6 \mathrm{H}_{2} \mathrm{O}} \\
+{ }^{2}\end{array}$ & $\begin{array}{l}+ \text { urea } \\
(12 \cdot 8 \mathrm{~g})\end{array}$ & $\begin{array}{l}0.05 \% \mathrm{Ce}^{3+} / \mathrm{Y}_{3} \mathrm{Al}_{5} \mathrm{O}_{12} \\
\text { (pale yellow) }\end{array}$ \\
\hline $\mathbf{A}$ & $\begin{aligned}+ & \mathrm{Y}\left(\mathrm{NO}_{3}\right)_{3} \cdot 6 \mathrm{H}_{2} \mathrm{O} \\
& (12 \cdot 252 \mathrm{~g})\end{aligned}$ & $\begin{aligned}+ & \mathrm{Ce}\left(\mathrm{NO}_{3}\right)_{3} \cdot 6 \mathrm{H}_{2} \mathrm{O} \\
& (0.0084 \mathrm{~g})\end{aligned}$ & $\begin{array}{l}+ \text { carbohydrazide } \\
(11.52 \mathrm{~g})\end{array}$ & $\begin{array}{l}0.05 \% \mathrm{Ce}^{3+} / \mathrm{Y}_{3} \mathrm{Al}_{5} \mathrm{O}_{12} \\
\text { (pale yellow) }\end{array}$ \\
\hline A & $\begin{array}{l}+\underset{(1 \cdot 05 \mathrm{~g})}{\mathrm{Ca}\left(\mathrm{NO}_{3}\right)_{2} \cdot 4 \mathrm{H}_{2} \mathrm{O}} \\
+{ }^{2}\end{array}$ & $\begin{array}{l}+\underset{(0.01 \mathrm{~g})}{\mathrm{Ce}\left(\mathrm{NO}_{3}\right)_{3} \cdot 6 \mathrm{H}_{2} \mathrm{O}}\end{array}$ & $\begin{array}{l}+ \text { urea } \\
(8.45 \mathrm{~g})\end{array}$ & $\begin{array}{l}0.14 \% \mathrm{Ce}^{3+} / \mathrm{CaAl}_{12} \mathrm{O}_{19} \\
\text { (yellow) }\end{array}$ \\
\hline $\mathbf{A}$ & $\begin{aligned}+ & \mathrm{Mg}\left(\mathrm{NO}_{3}\right)_{2} \cdot 6 \mathrm{H}_{2} \mathrm{O} \\
& (1 \cdot 24 \mathrm{~g})\end{aligned}$ & $\begin{aligned}+ & \mathrm{Ce}\left(\mathrm{NO}_{3}\right)_{3} \cdot 6 \mathrm{H}_{2} \mathrm{O} \\
(2 \cdot 18 \mathrm{~g}) & \end{aligned}$ & $\begin{array}{l}+ \text { urea } \\
(9 \cdot 22 \mathrm{~g})\end{array}$ & $\begin{array}{l}\mathrm{CeMgAl}_{11} \mathrm{O}_{19} \\
\text { (yellow) }\end{array}$ \\
\hline $\mathbf{A}$ & $\begin{aligned}+ & \mathrm{La}\left(\mathrm{NO}_{3}\right)_{3} \cdot 6 \mathrm{H}_{2} \mathrm{O} \\
& (2.098 \mathrm{~g}) \\
+ & \mathrm{Ce}\left(\mathrm{NO}_{3}\right)_{3} \cdot 6 \mathrm{H}_{2} \mathrm{O} \\
& (0.01 \mathrm{~g})\end{aligned}$ & $\begin{aligned}+\underset{(1.242 \mathrm{~g})}{\mathrm{Mg}}\left(\mathrm{NO}_{3}\right)_{2} \cdot 6 \mathrm{H}_{2} \mathrm{O} \\
+{ }^{2}\end{aligned}$ & 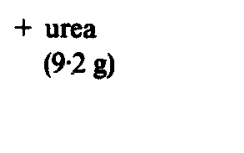 & $\begin{array}{l}0.14 \% \mathrm{Ce}^{3+} / \\
\mathrm{LaMgAl}_{11} \mathrm{O}_{19} \\
\text { (yellow) }\end{array}$ \\
\hline
\end{tabular}

$* \mathrm{~A}=\mathrm{Al}\left(\mathrm{NO}_{3}\right)_{3} \cdot 9 \mathrm{H}_{2} \mathrm{O}(20 \mathrm{~g})$. 
introduced into a muffle furnace $(l=28 \mathrm{~cm}, b=17 \mathrm{~cm}$ and $h=9 \mathrm{~cm})$ maintained at $500 \pm 10^{\circ} \mathrm{C}$. The mixture undergoes combustion for $\sim 2 \mathrm{~min}$ and gives a light pinkcoloured voluminous and foamy powder (weight $2.72 \mathrm{~g}, 100 \%$ yield) occupying the entire volume of the dish.

\subsection{Combustion synthesis of $0.05 \% \mathrm{Ce}^{3+}$-doped $\mathrm{Y}_{3} \mathrm{Al}_{5} \mathrm{O}_{12}(\mathrm{YAG})$}

$\mathrm{Al}\left(\mathrm{NO}_{3}\right)_{3} \cdot 9 \mathrm{H}_{2} \mathrm{O}(20 \mathrm{~g}), \mathrm{Y}\left(\mathrm{NO}_{3}\right)_{3} \cdot 6 \mathrm{H}_{2} \mathrm{O}(12 \cdot 252 \mathrm{~g})$ and carbohydrazide $(11 \cdot 52 \mathrm{~g})$ are dissolved in a minimum quantity of water along with $\mathrm{Ce}\left(\mathrm{NO}_{3}\right)_{3} \cdot 6 \mathrm{H}_{2} \mathrm{O}(0.0084 \mathrm{~g})$, (corresponding to $0.05 \% \mathrm{Ce}^{3+} / \mathrm{Y}_{3} \mathrm{AL}_{5} \mathrm{O}_{12}$, i.e. $0.05 \mathrm{~g} \mathrm{Ce}_{2} \mathrm{O}_{3}$ in $100 \mathrm{~g} \mathrm{Y}_{3} \mathrm{Al}_{5} \mathrm{O}_{12}$ ) in a cylindrical pyrex dish $(100 \mathrm{~mm}$ dia $\times 50 \mathrm{~mm}$ height $)$ of $300 \mathrm{ml}$ capacity. The dish is heated at $500^{\circ} \mathrm{C}$ for $<5 \mathrm{~min}$ in a muffle furnace as described above and gives a voluminous, pale yellow-coloured foam after combustion.

\subsection{Physical measurements}

The solid combustion products were characterized by powder X-ray diffraction patterns to confirm the formation of host lattices using a Philips X-ray diffractometer model $\mathrm{PW} 1050 / 70$ using $\mathrm{CuK} \alpha$ radiation with $\mathrm{Ni}$ filter. The presence of impurity ions in these host lattices was confirmed by their characteristic colours, UV-vis diffuse reflectance spectra, fluorescence spectra as well as decay time measurements. Reflectance spectra were recorded using a Shimadzu UV-vis spectrophotometer model UV-240 with $\mathrm{BaSO}_{4}$ as standard. Fluorescence spectra were obtained using a Hitachi $650-60$ fluorescence spectrophotometer as well as the decay time measurements.

Fluorescence decay times were measured using a pulsed laser decay time measurement unit indigenously fabricated. A schematic block diagram of the experimental arrangement is shown in figure 1.

In this, a pulsed nitrogen laser (150 KW, 8 ns and $10 \mathrm{pps})$, emitting at $337 \mathrm{~nm}$, pumps a dye laser ( $20 \mathrm{KW}, 4 \mathrm{~ns}$ and $10 \mathrm{pps}$ ), which emits at $409 \mathrm{~nm}$. The dye used is 2,5-diphenyl oxazole dissolved in toluene $\left(10^{-4} \mathrm{M}\right)$. The dye laser beam is focussed on to a powder sample which is mounted on a sample holder with a quartz window. The fluorescence of the sample collected at $90^{\circ}$ is focussed on the slit of a monochromator (Jobin Yuon). The output of the monochromator is focussed on a photo multiplier tube (EMI 9558B). The signals from the photo multiplier tube are fed to a storage oscilloscope (liwatsu DMS 6430). The data are collected from the storage oscilloscope by a computer (HP 4207) to which the storage oscilloscope is interfaced. The stored data are processed to obtain the decay curve, In (intensity) os time plot and the decay times.

\section{Results}

Combustion synthesized $\mathrm{Cr}^{3+}$ - and $\mathrm{Ce}^{3+}$-doped aluminous oxides showed $\mathrm{X}$-ray diffraction patterns similar to those of the parent lattices like $\alpha-\mathrm{Al}_{2} \mathrm{O}_{3}, \mathrm{Y}_{3} \mathrm{Al}_{5} \mathrm{O}_{12}$ etc. Typical XRD patterns of $\mathrm{Cr}^{3+} / \mathrm{Al}_{2} \mathrm{O}_{3}$ (ruby powder), $\mathrm{Cr}^{3+} / \mathrm{MgAl}_{2} \mathrm{O}_{4}$ and $\mathrm{Ce}^{3+} / \mathrm{Y}_{3} \mathrm{Al}_{5} \mathrm{O}_{12}$ are shown in figure 2. The lattice parameters calculated from these patterns are in good agreement with the literature values (Powder diffraction file 


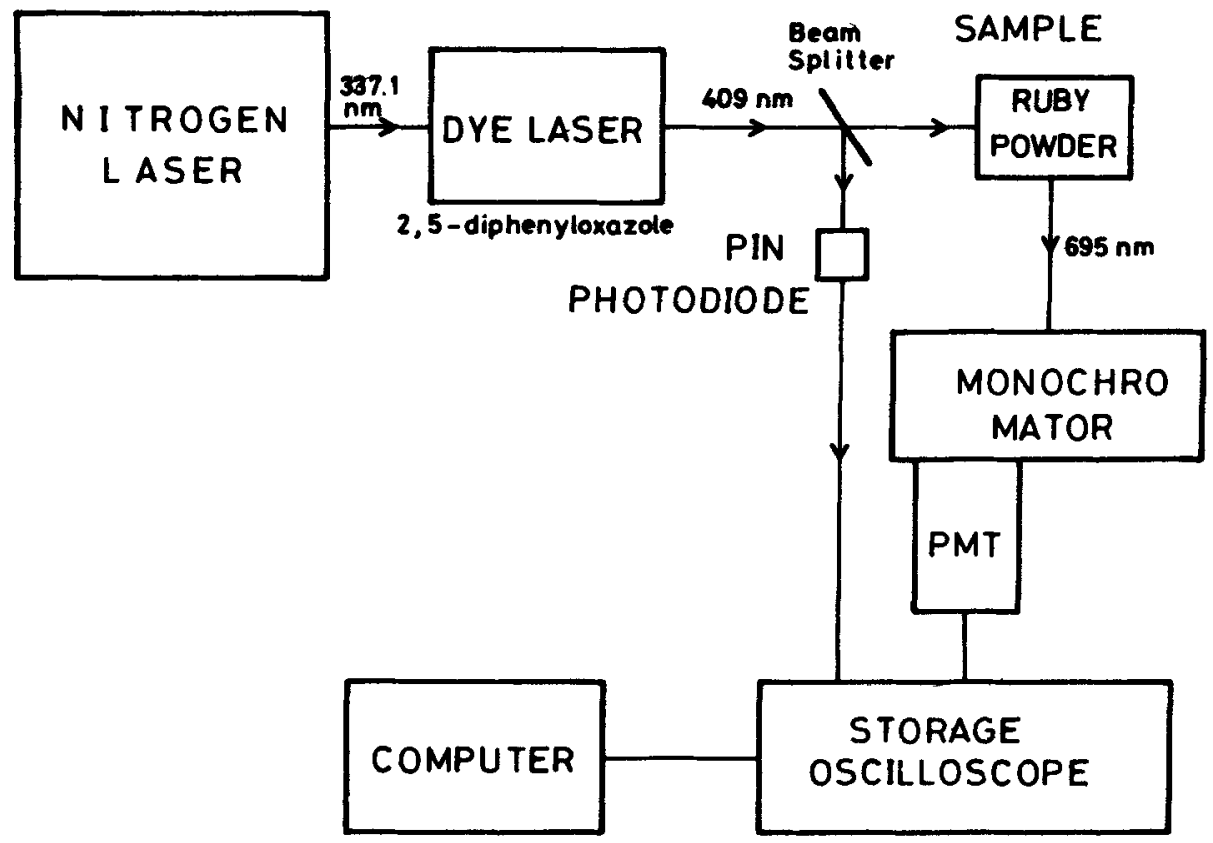

Figure 1. Schematic block diagram of pulsed laser decay time measurement unit.

1967). The calculated (reported) values for these oxides are as follows: (a) $\alpha-\mathrm{Al}_{2} \mathrm{O}_{3}$ $a=b=4.7719 \AA(4.758 \AA)$ and $c=13.0426 \AA$ (12.991 $\AA) ;(b) \mathrm{MgAl}_{2} \mathrm{O}_{4} a=8.1153 \AA$ (8.080 $\AA$ ); (c) $\mathrm{Y}_{3} \mathrm{Al}_{5} \mathrm{O}_{12} a=11.987 \AA(12.010 \AA)$. The presence of dopant ions in the host lattices was confirmed by their fluorescence spectra and characteristic colour (e.g. $\mathrm{Cr}^{3+} / \alpha-\mathrm{Al}_{2} \mathrm{O}_{3}$-pink; $\mathrm{Ce}^{3+} / \mathrm{Y}_{3} \mathrm{Al}_{5} \mathrm{O}_{12}$-yellow). These data have been summarized in table 2 .

\subsection{Properties of $\mathrm{Cr}^{3+} / \mathrm{Al}_{2} \mathrm{O}_{3}(\mathrm{ruby})$ powder}

Doping of aluminous oxides with $\mathrm{Cr}^{3+}$ ions involves atomic level substitution of the $\mathrm{Al}^{3+}$ ions present in these lattices by $\mathrm{Cr}^{3+}$ ions. Such substitutions invariably require high temperatures $\left(>1300^{\circ} \mathrm{C}\right)$ and long time periods. For example, formation of ruby $\left(\mathrm{Cr}^{3+}\right.$-doped $\left.\alpha-\mathrm{Al}_{2} \mathrm{O}_{3}\right)$ is known to take place when a $\mathrm{Cr}_{2} \mathrm{O}_{3}-$ $\mathrm{Al}_{2} \mathrm{O}_{3}$ mixture is heated at $\pm 1350^{\circ} \mathrm{C}$ for $96 \mathrm{~h}$ (De Biasi and Rodrigues 1981). It is gratifying that when a mixture containing $\mathrm{Al}\left(\mathrm{NO}_{3}\right)_{3} \cdot 9 \mathrm{H}_{2} \mathrm{O}(20 \mathrm{~g}), \mathrm{Cr}\left(\mathrm{NO}_{3}\right)_{3} \cdot 6 \mathrm{H}_{2} \mathrm{O}$ $(0.0148 \mathrm{~g})$ and urea $(8 \mathrm{~g})$ was used for the combustion at $500^{\circ} \mathrm{C}$, a light pink foamy powder was obtained. It was identified to be ruby $\left(\mathrm{Cr}^{3+}\right.$-ion doped $\left.\alpha-\mathrm{Al}_{2} \mathrm{O}_{3}\right)$ by its characteristic fluorescence spectra (Hirai et al 1987) (figure 3), UV-vis spectra (figure 4), decay time measurements (figure 5) and ESR spectrum (figure 6). Figure 3a shows the excitation spectrum of this as prepared from $0.05 \% \mathrm{Cr}^{3+} / \mathrm{Al}_{2} \mathrm{O}_{3}$ powder and figure $3 \mathrm{~b}$ shows the emission spectrum of the same. The characteristic emission band (Hirai et al 1987) (figure 3b), observed at $695 \mathrm{~nm}$ by exciting the ruby powder at $548 \mathrm{~nm}$ unequivocally proves the formation of ruby. That is, $\mathrm{Cr}^{3+}$-ions have replaced $\mathrm{Al}^{3+}$ ions at the ' $O_{h}$ ' sites in the $\alpha-\mathrm{Al}_{2} \mathrm{O}_{3}$ lattice. This characteristic emission band is attributed to the transition ${ }^{2} E_{2 g} \rightarrow{ }^{4} A_{2 g}$ of the $\mathrm{Cr}^{3+}$ 


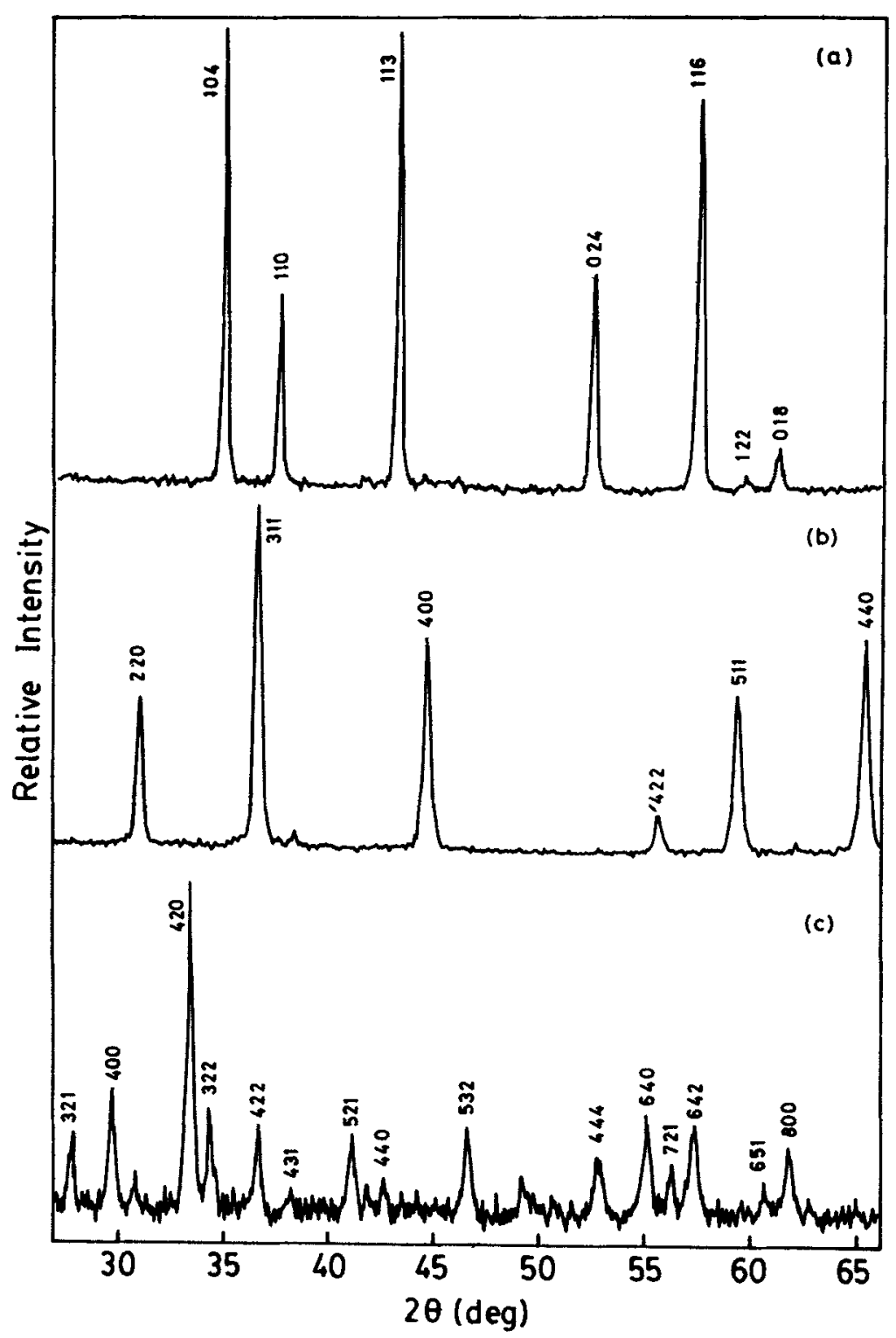

Figure 2. $\mathrm{X}$-ray powder diffraction patterns of fluorescent aluminous oxides] (a) ruby $\left(\mathrm{Cr}^{3+} / \mathrm{Al}_{2} \mathrm{O}_{3}\right)$, (b) $\mathrm{Cr}^{3+} / \mathrm{MgAl}_{2} \mathrm{O}_{4}$, and (c) $\mathrm{Ce}^{3+} / \mathrm{Y}_{3} \mathrm{Al}_{5} \mathrm{O}_{12}$ ( $\mathrm{Cu} \mathrm{K}$, radiation).

ion (Varsanyi et al 1959). The excitation spectrum of this ruby powder (figure 3a) shows two broad absorptions at $406 \mathrm{~nm}$ and $548 \mathrm{~nm}$, which are assigned to the ${ }^{4} A_{2 g} \rightarrow{ }^{4} T_{1 g}$ and ${ }^{4} A_{2 g} \rightarrow{ }^{4} T_{2 g}$ transitions of the $\mathrm{Cr}^{3+}$ ion respectively (Varsanyi $e t$ al 1959).

Formation of ruby was also confirmed by its characteristic UV-vis diffuse reflectance absorption spectrum (figure 4). The absorption bands at $402 \mathrm{~nm}$ and $555 \mathrm{~nm}$ could be assigned to the spectral transitions ${ }^{4} A_{2 g} \rightarrow{ }^{4} T_{1 g}$ and ${ }^{4} A_{2 g} \rightarrow{ }^{4} T_{2 g}$ of the $\mathrm{Cr}^{3+}$ ion respectively (Imbush 1978). A sharp but weak band observed at 
Table 2. Properties of combustion products.

\begin{tabular}{|c|c|c|c|c|c|c|}
\hline Fluorescent oxide products & $\begin{array}{c}\text { Surface } \\
\text { area } \\
\left(\mathrm{m}^{2} / \mathrm{g}\right)\end{array}$ & $\begin{array}{l}\text { Particle } \\
\text { size (from } \\
\text { surface } \\
\text { area) }(\mu \mathrm{m})\end{array}$ & $\begin{array}{c}50 \% \\
\text { Average } \\
\text { agglo- } \\
\text { merate }\end{array}$ & $\begin{array}{c}\text { Excitation } \\
\text { band } \\
(\mathbf{n m})\end{array}$ & $\begin{array}{c}\text { Emission } \\
\text { band } \\
(\mathrm{nm})\end{array}$ & $\begin{array}{c}\text { Decay } \\
\text { time } \\
\text { (ms) }\end{array}$ \\
\hline $0.05 \% \mathrm{Cr}^{3+} / \mathrm{Al}_{2} \mathrm{O}_{3}$ & $8 \cdot 3$ & 0.22 & $4 \cdot 3$ & 406,548 & 695 & 3.6 \\
\hline $0.05 \% \mathrm{Cr}^{3+} / \mathrm{MgAl}_{2} \mathrm{O}_{4}$ & 21.8 & $0 \cdot 10$ & $5 \cdot 2$ & 395,584 & 687 & $3 \cdot 95$ \\
\hline $0.05 \% \mathrm{Cr}^{3+} / \mathrm{LaAlO}_{3}$ & 3.5 & 0.35 & 1.2 & 514 & 734 & 52.0 \\
\hline $0.05 \% \mathrm{Ce}^{3+} / \mathrm{Y}_{3} \mathrm{Al}_{5} \mathrm{O}_{12}$ & $3 \cdot 3$ & 0.47 & 2.2 & 440,340 & 545 & $0 \cdot 104$ \\
\hline $0.14 \% \mathrm{Ce}^{3+} / \mathrm{CaAl}_{12} \mathrm{O}_{19}$ & 8.5 & 0.25 & $4 \cdot 1$ & 265 & 325 & - \\
\hline $\mathrm{CeMgAl}_{11} \mathrm{O}_{19}$ & $20-2$ & 0.15 & $3 \cdot 2$ & 281 & 370 & - \\
\hline $0.14 \% \mathrm{Ce}^{3+} / \mathrm{LaMgAl}_{11} \mathrm{O}_{19}$ & $18 \cdot 0$ & 0.20 & $3 \cdot 4$ & 275 & 337 & - \\
\hline
\end{tabular}

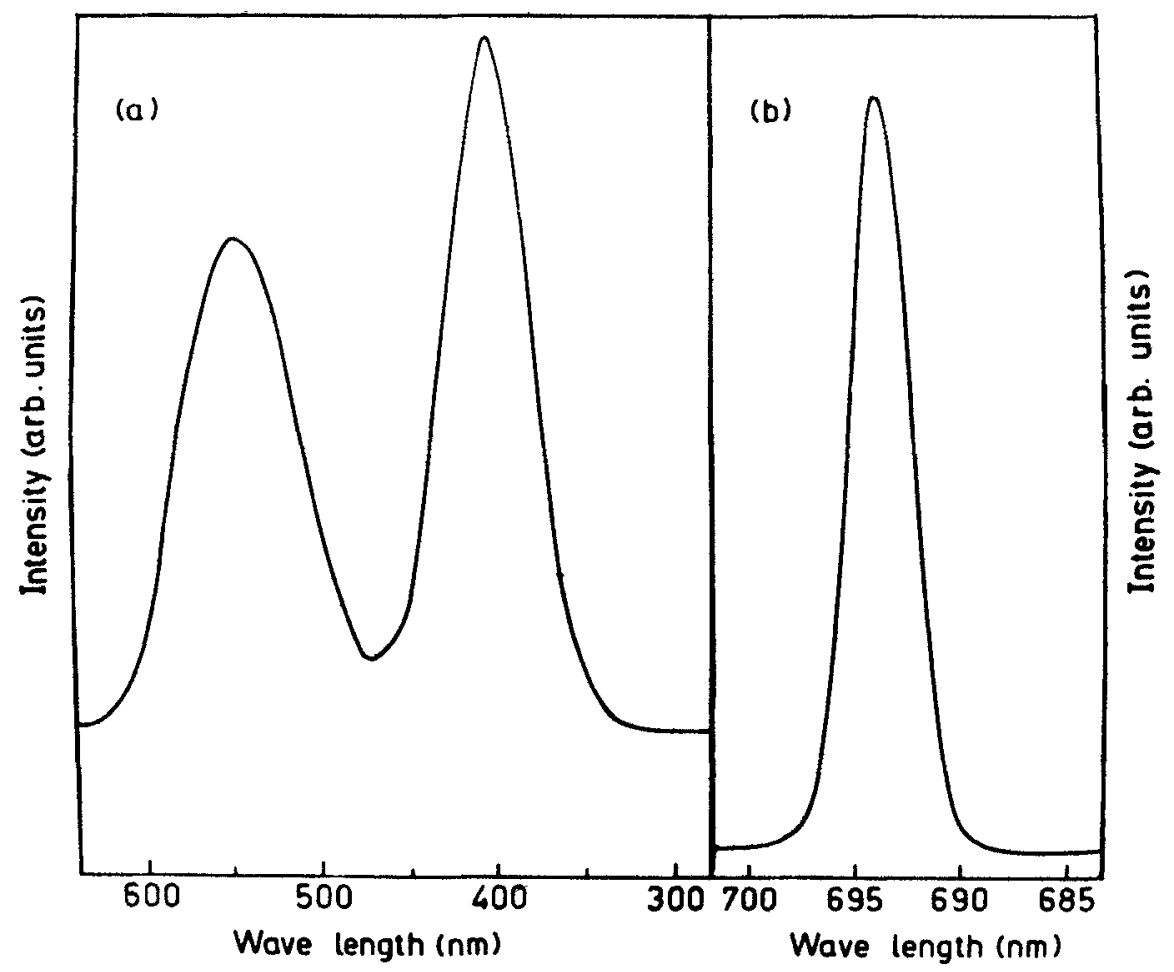

Figure 3. Fluorescence spectra of the as-prepared ruby powder: (a) excitation spectrum and (b) emission spectrum.

$695 \mathrm{~nm}$ could be attributed (Imbush 1978) to the spin forbidden transition ${ }^{4} A_{2 g}$ $\rightarrow{ }^{2} E_{2 g}$.

Formation of ruby $\left(0.05 \% \mathrm{Cr}^{3+}\right.$-doped $\left.\alpha-\mathrm{Al}_{2} \mathrm{O}_{3}\right)$ powder was further confirmed by its decay time using pulsed-laser decay-time measurement. The decay curve of this powder is shown in figure 5a. It shows a characteristic decay of $\mathrm{Cr}^{3+}$ in the $\alpha$ $\mathrm{Al}_{2} \mathrm{O}_{3}$ lattice. The decay is single exponential in nature which is further confirmed by its straight line fit in the $\ln$ (intensity) vs time plot (figure 5 b). The decay time of $\mathrm{Cr}^{3+}$ in this powder, calculated from the slope of this In (intensity) $v s$ time plot, is 


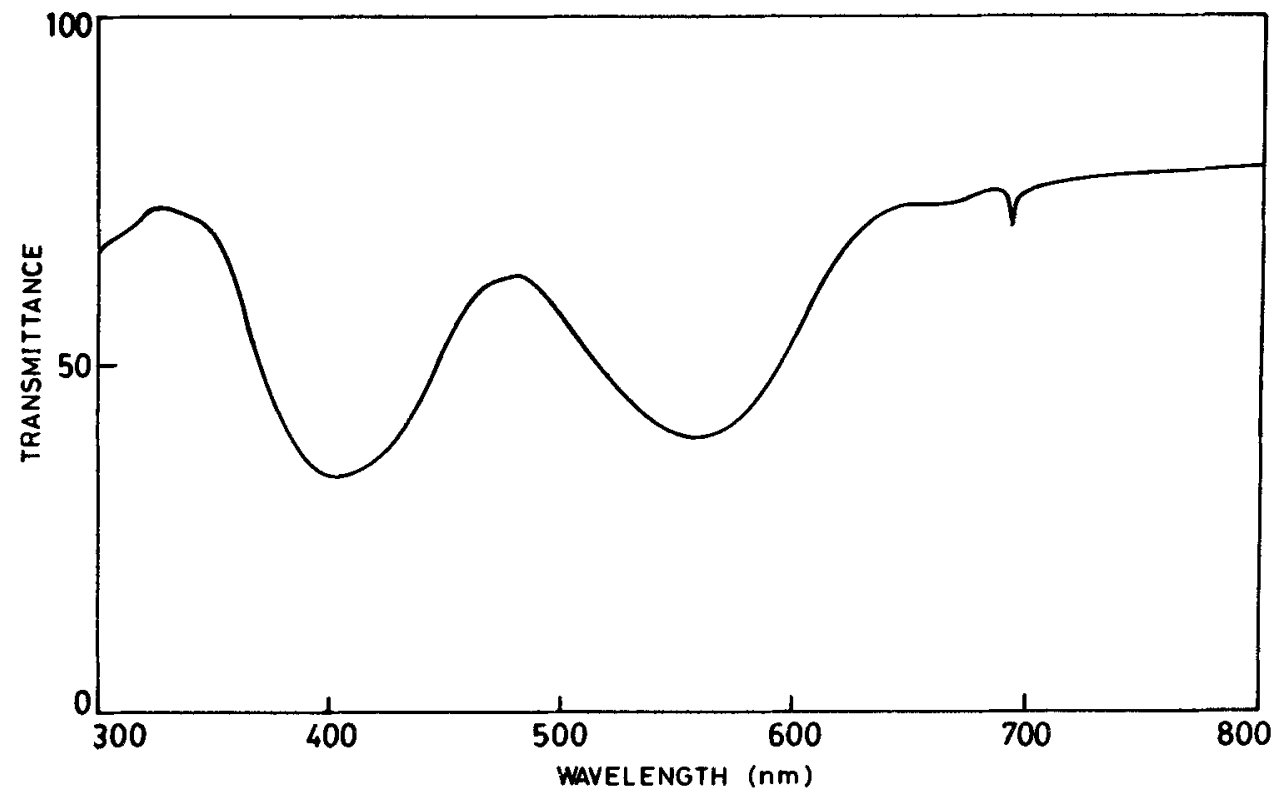

Figure 4. UV-vis diffuse reflectance absorption spectrum of the as-prepared ruby powder.

$3.6 \mathrm{~ms}$. This value is comparable with $4.2 \mathrm{~ms}$ reported in the literature for single crystal ruby at room temperature (Maiman et al 1961; Cronemeyer 1964; Nelson and Sturge 1965; Mahan et al 1969).

The presence of $\mathrm{Cr}^{3+}$ in $\mathrm{Al}_{2} \mathrm{O}_{3}$ was also identified by electron spin resonance (ESR) spectra of the powder. The ESR spectrum of the combustion-synthesized ruby powder (figure 6) is similar to that reported in the literature (De Biasi and Rodrigues 1985).

The combustion mixture containing higher concentrations of $\mathrm{Cr}^{3+}$ ions (such as the one used in the experimental section) also resulted in the formation of ruby powder having an intense pink colour and gave fluorescence spectra exactly similar to figure 3 . It is worth mentioning that combustion-synthesized ruby powders with more than $2 \% \mathrm{Cr}^{3+} / \mathrm{Al}_{2} \mathrm{O}_{3}$ had traces of green colour in some portions due to the presence of unreacted $\mathrm{Cr}_{2} \mathrm{O}_{3}$. This could be due to the comparatively short period for which the high in situ temperatures prevail in the combustion process. It may be noted that $\mathrm{Cr}_{2} \mathrm{O}_{3}: \mathrm{Al}_{2} \mathrm{O}_{3}$ forms solid solutions in the entire range only after long heat-treatment as in metallurgical processes (Jacob 1978).

Thus it was possible to dope desired concentrations of $\mathrm{Cr}^{3+}$ ion (up to $2 \%$ ) in $\alpha$ $\mathrm{Al}_{2} \mathrm{O}_{3}$ to obtain ruby in powder form by the combustion of aluminium nitrate-urea mixtures containing chromium nitrate. Formation of homogeneous single phase ruby powder not only demonstrates the capability of the combustion process in the atomic level doping of impurity ions in the host lattices but also confirms the highly exothermic (flame temperature $\geqslant 1350^{\circ} \mathrm{C}$ ) nature of combustion.

\subsection{Properties of $\mathrm{Cr}^{3+}$-doped $\mathrm{MgAl}_{2} \mathrm{O}_{4}$ and $\mathrm{LaAlO}_{3}$}

The combustion process used for the preparation of ruby powder could also be 

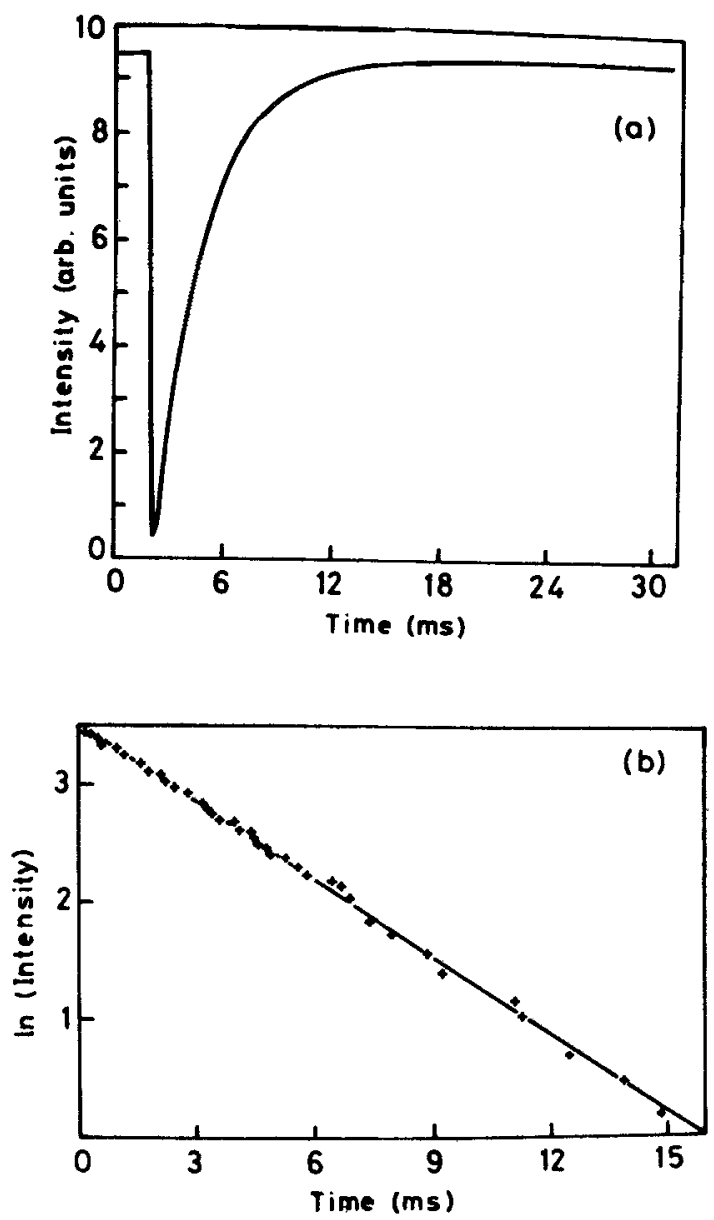

Figure 5. (a) The decay curve of ruby powder and (b) In (intensity) vs time plot of ruby powder.

used to prepare other $\mathrm{Cr}^{3+}$-doped aluminous oxides like $\mathrm{Cr}^{3+} / \mathrm{MgAl}_{2} \mathrm{O}_{4}$ and $\mathrm{Cr}^{3+} / \mathrm{LaAlO}_{3}$ by the combustion of corresponding metal nitrate-aluminium nitrate-urea mixtures containing chromium nitrate. The actual compositions used for their synthesis are given in table 1 . The formation of these doped oxides e.g. $\mathrm{Cr}^{3+} / \mathrm{MgAl}_{2} \mathrm{O}_{4}$ have been confirmed by their characteristic pink colour, XRD (figure 2) and fluorescence spectra (Wood et al 1968; McCarthy and Gudel 1988). The fluorescence spectral data for these doped oxides are summarized in table 1 . The fluorescence spectra of $0.05 \% \mathrm{Cr}^{3+} / \mathrm{MgAl}_{2} \mathrm{O}_{4}$ are shown in figures 7 and 8 . The observed emission. band at $687 \mathrm{~nm}$ and the excitation bands at 395 and $584 \mathrm{~nm}$ agree well with the literature values (Wood et al 1968).

Although all these lattices have $\mathrm{Cr}^{3+}$ ions in octahedral co-ordination, they show emission at different frequencies. This could be attributed to the difference in lattice pressures experienced by the $\mathrm{Cr}^{3+}$ ions. A similar interpretation has been given by Orgel (1957) for the difference in the spectra of $\mathrm{Cr}^{3+}$-doped alum and $\mathrm{Cr}^{3+}$-doped alumina (ruby). 


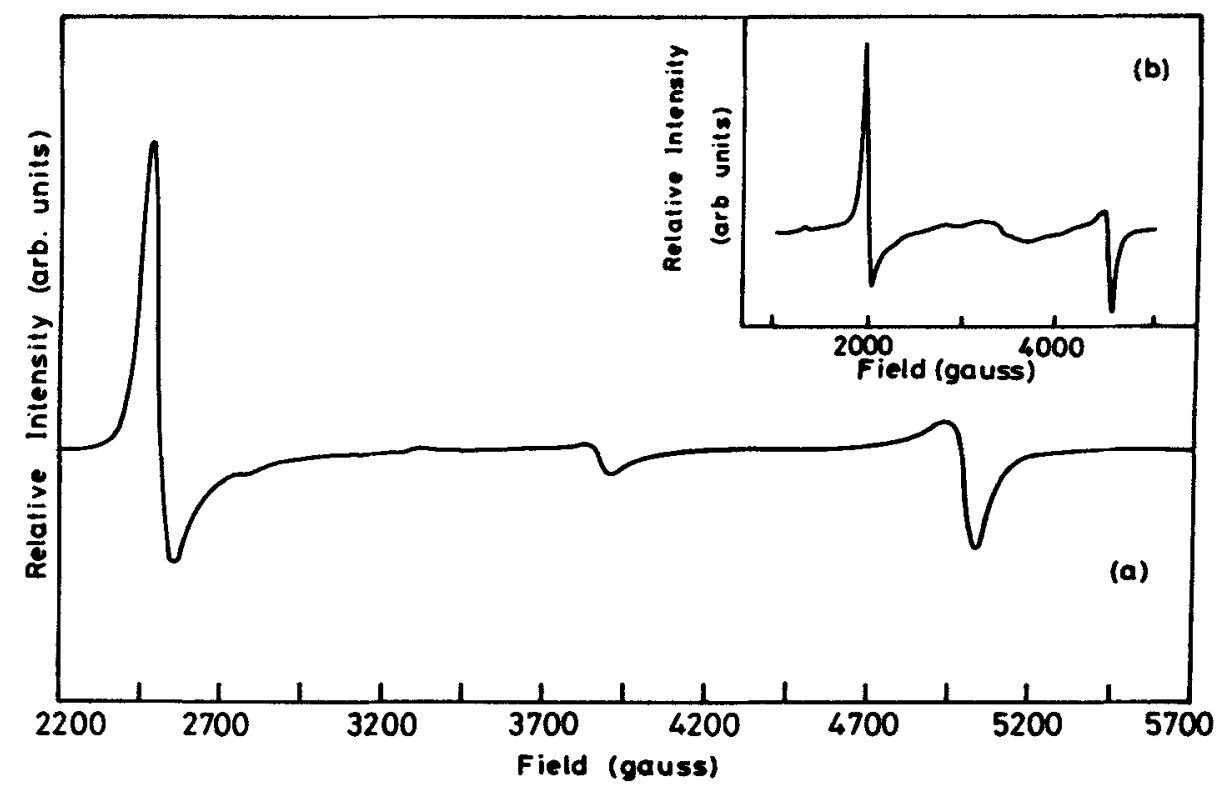

Figure 6. The ESR spectrum of (a) the combustion synthesized ruby powder $(0-05 \mathrm{wt} . \%$ $\mathrm{Cr}^{3+} / \mathrm{Al}_{2} \mathrm{O}_{3}$ ) and (b) ruby powder (Di Biasi and Rodrigues 1985).

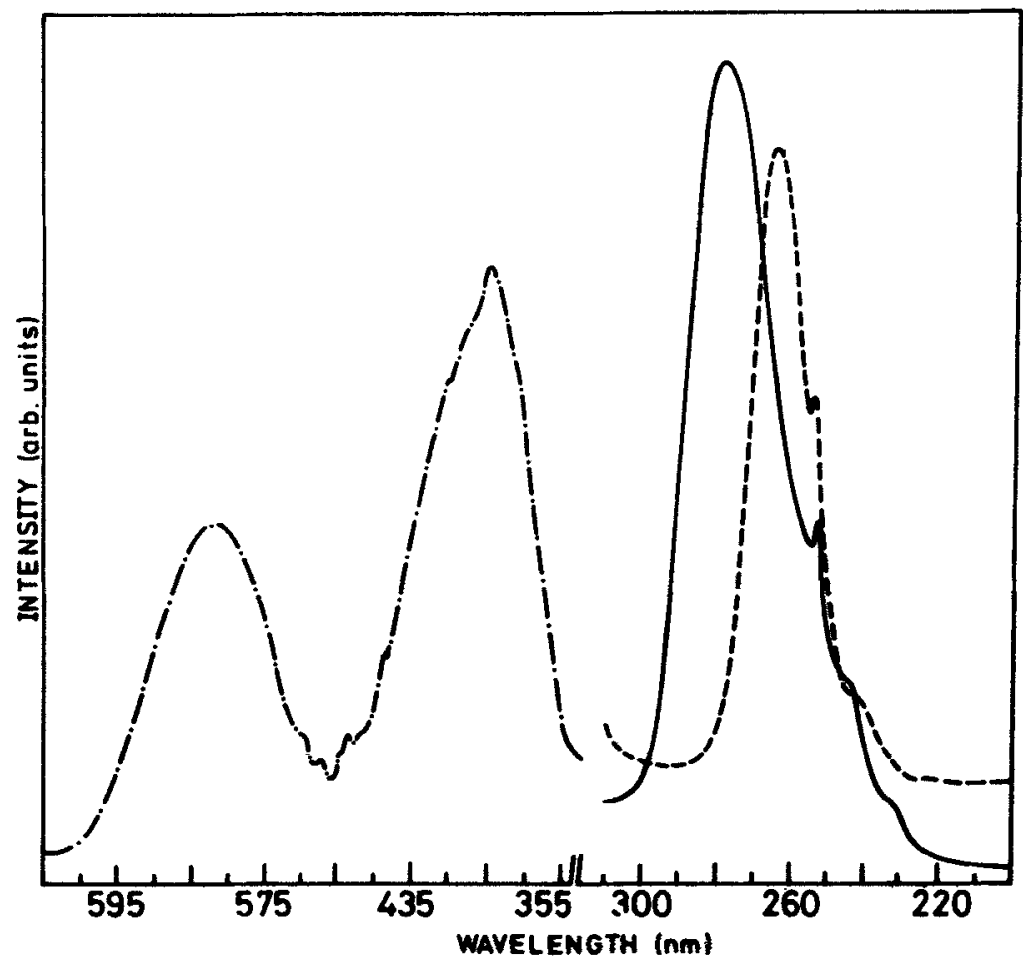

Figure 7. Excitation spectra of the fluorescence in $0.05 \mathrm{wt} \% \mathrm{Cr}^{3+} / \mathrm{MgAl}_{2} \mathrm{O}_{4}(-\cdot \cdots-)$ $\mathrm{CaAl}_{12} \mathrm{O}_{19}: 0.14 \mathrm{Ce}^{3+}(---) ; \mathrm{CeMgAl}_{11} \mathrm{O}_{19}(-)$. 


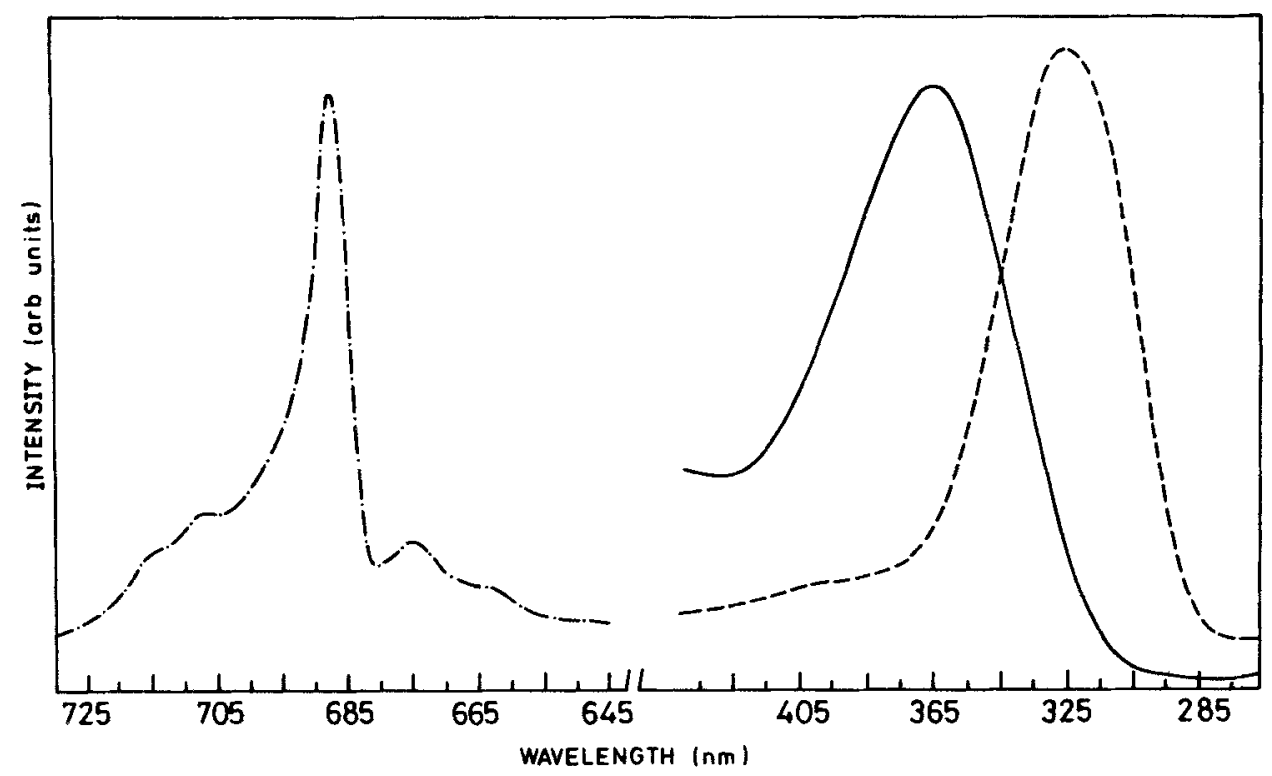

Figure 8. Emission spectra of the fluorescence in $0.05 \mathrm{wt} \% \mathrm{Cr}^{3+} / \mathrm{MgAl}_{2} \mathrm{O}_{4}(-\cdot \cdot-\cdot)$; $\mathrm{CaAl}_{12} \mathrm{O}_{19}: 0.14 \mathrm{Ce}^{3+}(---) ; \mathrm{CeMgAl}_{11} \mathrm{O}_{19}(-)$.

The decay time values of $0.05 \% \mathrm{Cr}^{3+} / \mathrm{MgAl}_{2} \mathrm{O}_{4}$ and $\mathrm{Cr}^{3+} / \mathrm{LaAlO}_{3}$ are $3.9 \pm 0.5 \mathrm{~ms}$ and $52 \pm 0.5 \mathrm{~ms}$ respectively. $\mathrm{Cr}^{3+} / \mathrm{LaAlO}_{3}$ is of particular interest due to its longer decay time $(52 \mathrm{~ms})$ (slow decay). Many of the energy transfer processes are explained and well understood from the optical spectra of $\mathrm{Cr}^{3+} / \mathrm{LaAlO}_{3}$ (Siebold and Heber 1981).

\subsection{Properties of $\mathrm{Ce}^{3+}$-doped aluminous oxides}

Cerium (III)-doped aluminous oxides like $\mathrm{Ce}^{3+} / \mathrm{Y}_{3} \mathrm{Al}_{5} \mathrm{O}_{12}, \mathrm{Ce}^{3+} / \mathrm{CaAl}_{12} \mathrm{O}_{19}$, $\mathrm{Ce}^{3+} / \mathrm{LaMgAl}_{11} \mathrm{O}_{19}$ and $\mathrm{CeMgAl}_{11} \mathrm{O}_{19}$ have been prepared by the combustion of respective metal nitrate-aluminium nitrate-urea mixtures containing $\mathrm{Ce}\left(\mathrm{NO}_{3}\right)_{3} \cdot 6 \mathrm{H}_{2} \mathrm{O}$. The actual compositions used for their syntheses are given in table 1. Formation of these $\mathrm{Ce}^{3+}$-doped oxides was confirmed by their characteristic XRD (figure 2) and fluorescence spectra. Typical fluorescence spectra of $0.14 \% \mathrm{Ce}^{3+} / \mathrm{CaAl}_{12} \mathrm{O}_{19}$ and $\mathrm{CaMgAl}_{11} \mathrm{O}_{19}$ are given in figures 7 and 8. The emission wavelengths of $0 \cdot 14 \%$ $\mathrm{Ce}^{3+} / \mathrm{CaAl}_{12} \mathrm{O}_{19}$ and $\mathrm{CeMgAl}_{11} \mathrm{O}_{19}$ are observed at $325 \mathrm{~nm}$ and $370 \mathrm{~nm}$ respectively. These results are in good agreement with the literature (Vertegan et al 1973; Stevels 1978). The shape of the $\mathrm{Ce}^{3+}$ emission band in $\mathrm{CeMgAl}_{11} \mathrm{O}_{19}$ is as reported (Vertegan et al 1973) and is similar to that of $\mathrm{CeF}_{3}$ and $\mathrm{CePO}_{4}$ (Blasse and Bril 1969).

The characteristic (Holloway and Kestigian 1967; Stevels 1978) excitation and emission wavelengths observed for $0.05 \% \mathrm{Ce}^{3+} / \mathrm{Y}_{3} \mathrm{Al}_{5} \mathrm{O}_{12}$ (Holloway and Kestigian $1967)$ and $0.14 \% \mathrm{Ce}^{3+} / \mathrm{LaMgAl}_{11} \mathrm{O}_{19}$ (Stevels 1978) are given in table 2 . The decay time of $\mathrm{Ce}^{3+} / \mathrm{YAG}$ is $104 \mu$ s (table 2). It was interesting to observe the very bright yellow fluorescence of $\mathrm{Ce}^{3+} / \mathrm{YAG}$ under the nitrogen laser during decay time measurements.

The $\mathrm{Ce}^{3+}$-ion doped aluminous oxides like $\mathrm{Ce}^{3+} / \mathrm{CaAl}_{12} \mathrm{O}_{19}, \mathrm{Ce}^{3+} / \mathrm{YAG}$ and 
$\mathrm{CeMgAl}_{11} \mathrm{O}_{19}$ are fine powders and have particle sizes of 0.2 to $0.8 \mu \mathrm{m}$ in agglomerates sizes of $2-4 \mu \mathrm{m}$. These fine particle oxides are of interest for application as phosphors in TV screens and in fluorescent lamps.

\section{Conclusions}

Fine particles of fluorescent aluminous oxides like $\mathrm{Cr}^{3+} / \alpha-\mathrm{Al}_{2} \mathrm{O}_{3}, \mathrm{Cr}^{3+} / \mathrm{MgAl}_{2} \mathrm{O}_{4}$, $\mathrm{Cr}^{3+} / \mathrm{LaAlO}_{3}, \mathrm{Cr}^{3+} / \mathrm{YAG}, \mathrm{Ce}^{3+} / \mathrm{YAG}, \mathrm{Ce}^{3+} / \mathrm{CaAl}_{12} \mathrm{O}_{19}, \mathrm{Ce}^{3+} / \mathrm{LaMgAl}_{11} \mathrm{O}_{19}$ and $\mathrm{CeMgAl}_{11} \mathrm{O}_{19}$ have been successfully prepared by the combustion of the corresponding metal nitrate-urea/carbohydrazide mixtures at $500^{\circ} \mathrm{C}$ in less than $5 \mathrm{~min}$. The combustion process not only yields a homogenous and stoichiometric product but also helps in atomic level substitution of impurity ions for $\mathrm{Al}^{3+}$ ions in the host lattice due to the high in situ temperatures $\left(>1300^{\circ} \mathrm{C}\right)$ that prevail during the incandescent combustion. Some fluorescent properties of these fine particle oxide materials and decay time characteristics have been studied.

\section{References}

Blasse G and Bril A 1969 J. Chem. Phys. 513252

Cokayne B 1972 in Modern oxide materials (eds) B Cokayne and D W Jones (New York: Academic Press) p 1

Cronemeyer O C 1964 J. Opt. Soc. Am. 561703

De Biasi R S and Rodrigues D C S 1981 J. Mater. Sci. 16968

De Biasi R S and Rodrigues D C S 1985 J. Am. Ceram. Soc. 68409

Geusic J E, Marcus H M and Van Uitert L G 1966 Proc. Conf. Physics of Quantum Electronics (New York: McGraw-Hill) p. 725

Gillen R D and Salomon R E 1970 J. Phys. Chem. 744252

Hannay N B 1973 XXIVth International Congress of Pure and Applied Chemistry Vol. 3, p: 1

Hirai Y, Fukuda T, Kobayashi Y, Kuwahara H, Kido Y and Kubota K 1987 Solid State Commun. 62637

Hollcway W W Jr. and Kestigian M 1967 Phys. Lett. A25 514

Imbusch G F 1978 in Luminescence spectroscopy (ed.) M D Lumb (New York: Academic Press) p. 1

Jacob K T 1978 J. Electrochem. Soc. 125175

Kingsley J J and Patil K C 1988 Mater. Lett. $6427-432$

Kingsley J J, Sunder Manoharan S and Patil K C 1988a Ist Soviet Indian Seminar on Rare Earth and Actinide Compounds, September 19-21 Tallin, USSR

Kingsley J J, Sunder Manoharan S, Suresh K and Patil K C 1988b 2nd International Conference on Ceramic Powder Processing Science, October 12-14 (1988), Berchtesgaden, Bavaria, FRG, Deutsche Keramische Gesellschaft e.V (DKG), Abstract in: TIZ International 1988112726

Kingsley J J, Suresh K and Patil K C 1990 J. Mater. Sci. 251305

Leunng K M 1986 Phys. Rev. A33 2461

Mahan A I, Bitterli C, Cannor S M and Grant D G 1969 J. Opt. Soc. Am. 5949

Maiman T H, Hoskins R H, D'Haenens I T, Asawa C K and Evtuhov V 1961 Phys. Rev. 1231151

McCarthy P J and Gudel H U 1988 Coord. Chem. Revs. 8866

Nelson D F and Sturge M D 1965 Phys. Rev. A137 1117

Orgel L F 1957 Nature (London) 1791348

Powder Diffraction File 1967 Inorganic Vol. PDIS-10, Joint Committee on Diffraction Standards, Pennsylvania

Scholten P C and Eijnthoven R 1985 Eur. Patent Appl. EP 140,448; (1985) Chem. Abstr. 103 30124f

Siebold $H$ and Heber $J 1981 \mathrm{~J}$. Luminescence 23325

Stevels A L N 1978 J. Electro. Chem. Soc. 125

Varsanyi F, Wood D L and Schawlow A L 1959 Phys. Rev. Lett. 3544

Vertegan J M P J, Sommerdijk J L and Verriet J G 1973 J. Luminescence 6425

Wolfe W R 1978 US patent 4,088,922; (1978) Chem. Abstr. 89 121750r

Wood D L, Imbusch G F, Mac Farlane R M, Kisliuk P and Larkin D M 1968 J. Chem. Phys. 485255 